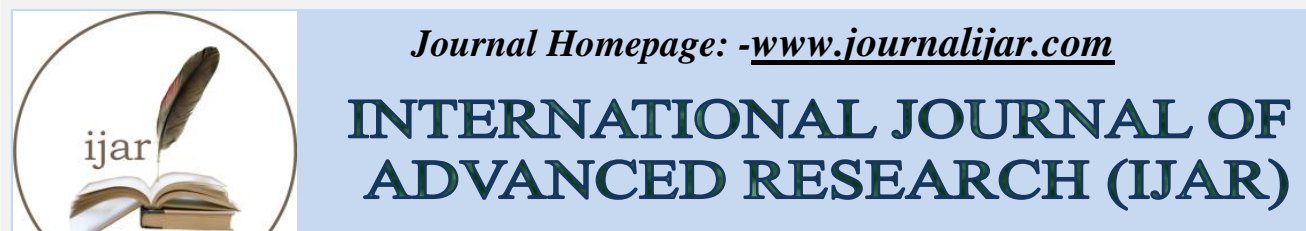

Article DOI: $10.21474 / \mathrm{IJAR} 01 / 9440$

DOI URL: http://dx.doi.org/10.21474/IJAR01/9440

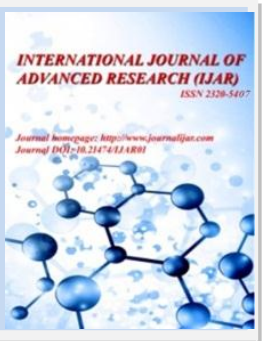

RESEARCH ARTICLE

\title{
ASSOCIATION BETWEEN SERUM URIC ACID LEVEL AND NODAL OSTEOARTHRITIS IN A SAMPLE OF MIDDLE AGED IRAQI FEMALES.
}

\author{
Dr. Juman Ali Nasir ${ }^{1}$,Dr. Waseem Kamil Kaith ${ }^{2}$ and Dr. Mohammed Hadi Alosami ${ }^{3}$. \\ 1. M.B.Ch.B. Baghdad Teaching Hospital. \\ 2. M.B.Ch.B., Diploma in (Rheum \& Rehab.) Rheumatology specialist at Al-Yarmouk Teaching Hospital. \\ 3. C.A.B.M., F.I.B.M.S. (Rheum. \& Rehab.) Assistant professor, Consultant Rheumatologist, College of \\ Medicine/Baghdad University.
}

\section{Manuscript Info}

Manuscript History

Received: 24 May 2019

Final Accepted: 26 June 2019

Published: July 2019

Key words:-

Nodal osteoarthritis, Uric acid, Heberden's nodule.

\section{Abstract}

Background: Nodal osteoarthritis (NOA) a subset of OA, is characterized by polyarticular interphalangeal and thumb base OA, Heberden's nodes are a classic sign of hand osteoarthritis, which is presented in the distal interphalageal joint. The epidemiologic relationship between hyperuricemia and $\mathrm{OA}$ raises the question of whether data support a biologic relation of the two entities.

Patients and methods: A case-control study. A total of 100 patients (50 cases with nodal osteoarthritis and 50 healthy control) aged from (40 to 70) years old were included in the study.

Results: There was no significant association between serum uric acid and nodal osteoarthritis. Age, and high body mass index was positively correlated to nodal osteoarthritis. There was positive relationship between serum uric acid and radiological osteoarthritic changes of hand which has been assessed by using Kellgren-Lawrence scale (P-value < 0.001).

Conclusion: Serum uric acid can be used as a mean to give us an idea about radiological osteoarthritic changes of hand assessed by using Kellgren-Lawrence scale.

Copy Right, IJAR, 2019,. All rights reserved.

\section{Introduction:-}

Osteoarthritis (OA) is the leading cause of arthritis in the world affecting 10-15\% of adults, with a lifetime risk as high as $50 \%{ }^{(1)}$. Nodal osteoarthritis (NOA) is a subset of OA, Heberden's nodes are a classic sign of hand osteoarthritis, and Bouchard's nodes is predominant in women and has a clear genetic predisposition ${ }^{(2)}$. The incidence of hand osteoarthritis in people over 55 years of age was $13.4 \%$ for men and $26.2 \%$ for women, and these levels are increased with age ${ }^{(3)}$. OA affects 302 million worldwide ${ }^{(4)}$.

Being obese female aged more than 40 years, at menopause, has history of OA, high bone density, and joint laxity all are considered as risk factors for NOA ${ }^{(5)}$. It is presented clinically by the following classical symptoms: joint pain, morning stiffness (of $<1 / 2$ hour in duration), and loss of motor function ${ }^{(6)}$.

Corresponding Author:-Dr. Juman Ali Nasir.

Address:-M.B.Ch.B. Baghdad Teaching Hospital. 
On examination; crepitus, joint effusion and Heberden's and Bouchard's nodes were found. Osteoarthritis, although considered as a degenerative consequence of aging, is a disease with an increasingly well-characterized molecular pathophysiology. Biomechanical factors, obesity, and malignant, result in chemical alterations within the joint that promote cartilage degradation ${ }^{(7)}$.

Uric acid (UA) in human is the main final product of purine metabolism ${ }^{(8)}$. Hyperuricemia was recently defined as above $7.7 \mathrm{mg} / \mathrm{dl}$ in men and above $6.6 \mathrm{mg} / \mathrm{dl}$ in women ${ }^{(9)}$, or above $7.0 \mathrm{mg} / \mathrm{dl}$ in men and above $5.7^{(10)}$ or $6 \mathrm{mg} / \mathrm{dl} \mathrm{in}$ women ${ }^{(11)}$.

The epidemiologic relationship between hyperuricemia and OA raises the question of whether data support a biologic relation of the two entities. Four possibilities deserve consideration: presence of shared risk factors (e.g., obesity), rather than any direct relationship; osteoarthritis in a joint might promote urate crystallization locally; monosodium urate (MSU) crystal deposition on/in cartilage may create local mechanical and/or inflammatory damage promoting OA development; urate may function intrinsically in the process of OA development and/or $\operatorname{progression}^{(12)}$.

\section{Aim of study:}

This study was conducted to assess the relationship between level of serum uric acid and hand osteoarthritis in middle aged Iraqi females.

\section{Patients and method:- Study Design:}

A case-control study conducted at Baghdad Teaching Hospital, Unit of Rheumatology during the period from October 2018 through April 2019, after approval of the study protocol by University of Baghdad, College of Medicine, Department of Medicine, Rheumatology and Medical Rehabilitation Unit.

\section{Sample selection:}

A total of 100 patients (50 cases and 50 healthy control) aged from (40 to 70) years old were enrolled in this study, cases were met the Criteria designed for classification of hand osteoarthritis which published by American College of Rheumatology in 1990 (6). Participants were excluded if they were: 1- having history of hypertension, diabetes mellitus, renal or heart disease. 2- history of gout, psoriasis or psoriatic arthritis, rheumatoid arthritis. 3- drugs that affect level of serum uric acid like: Anti-TB medications (ethambutol, pyrazinamide), thiazide diuretics, cyclosporine, aspirin. 4- malignancy and use of chemotherapy.

\section{Methods and Data collection:}

data were collected by a questionnaire designed for the purpose of the study. It collected data about:

\section{Socio-demographic data:}

which include: Age, gender, weight (in kilogram), height (in meter), body mass index (BMI), education level, and smoking status, alcohol consumption, marital status . Body mass index (BMI) was calculated.

\section{Laboratory data:}

Blood samples were obtained from all participants for measuring serum uric acid, complete blood count (CBC), erythrocyte sedimentation ratio (ESR), rheumatoid factor (RF), blood urea (B. Urea), serum creatinine (S.Cr), blood sugar, all of them except serum uric acid were obtained to exclude other diseases.

the reference range of SUA is typically $3.4-7.2 \mathrm{mg} / \mathrm{dL}(200-430 \mu \mathrm{mol} / \mathrm{L})$ for males, and 2.4-6.1 mg/dL (140-360 $\mu \mathrm{mol} / \mathrm{L})$ for females ${ }^{(11)}$.

\section{Radiological data:}

Bilateral hand plain x-ray postereoanterior view (PA) were obtained for all participants and the severity of hand osteoarthritis was assessed by using Kellgren-Lawrence (KL) grading system. The Kellgren-Lawrence uses four radiographic features: joint space narrowing, osteophytes, subchondral sclerosis, and deformity. The severity of radiographic changes increases from grade 0 to 4 with grade 0 meaning no radiographic features of osteoarthritis while grade 4 means large osteophytes marked joint space narrowing, severe sclerosis, and definite bony deformity (13). 


\section{Statistical Analysis:}

Statistical Package for the Social Sciences (SPSS) Software V 23 was used to perform statistical analysis. Data were presented as numbers, percentages, and mean. Chi-square test and its correction Fisher exact test, Student's t-test were used to measure the significancy. Correlations were assessed using Pearson's correlation coefficient. P value of $<0.05$ was considered statistically significant.

\section{Ethical issue:}

Informed consent was obtained from each participant included in this study according to the declaration of Helsinki. Data and information of the participants were kept confidentially. This study was approved by the ethical committee of Baghdad University, College of Medicine-Medical Department.

\section{Results:-}

The study group (cases) composed of 50 patients with nodal osteoarthritis, and control group composed of 50 apparently healthy controls. Age of participants ranged from 40 years to 70 years, with a mean of (53.4 \pm 7.2$)$.

BMI of the study participants ranged from $(19.1) \mathrm{Kg} / \mathrm{m}^{2}$ to $(46.7) \mathrm{Kg} / \mathrm{m}^{2}$ with a mean of $(32.03 \pm 6.51) \mathrm{Kg} / \mathrm{m}^{2}$ and a median of (31.13) $\mathrm{Kg} / \mathrm{m}^{2}$. Table-1 compares the BMI status of the two study groups. There was a statistically significant difference in BMI between the two study groups $=2.95(P=0.004)$.

Table 1:-Body mass index of the study groups.

\begin{tabular}{|c|c|c|c|c|}
\hline & \multicolumn{3}{|c|}{ Study group } & \multirow{2}{*}{$\begin{array}{c}\text { Student's } \\
\text { t- test }\end{array}$} \\
\hline BMI & Cases $(n=50)$ & Control $(\mathrm{n}=50)$ & Total $(\mathrm{n}=100)$ & \\
\hline Range & $19.10-46.14$ & $22.58-46.68$ & $19.10-46.68$ & \multirow[t]{2}{*}{0.004} \\
\hline Mean \pm SD & $30.18 \pm 6.90$ & $33.88 \pm 5.58$ & $32.03 \pm 6.51$ & \\
\hline
\end{tabular}

Table 2 represented the Comparison of BMI classes between the two study groups it again showed statistically significant difference, by chi-square test $14.5(P=0.006)$.

Table 2:-Body mass index classes of the study groups

\begin{tabular}{|c|c|c|c|c|}
\hline \multirow[t]{2}{*}{ BMI Classification } & \multicolumn{3}{|c|}{ Study sample } & \multirow[b]{2}{*}{ P-value } \\
\hline & Case $(n=50)$ & $\begin{array}{c}\text { Control } \\
(\mathbf{n}=50)\end{array}$ & $\begin{array}{c}\text { Total } \\
(\mathrm{n}=100)\end{array}$ & \\
\hline Normal $(18.5-24.9)$ & $13(26.0 \%)$ & $2(4.0 \%)$ & $15(15.0 \%)$ & \multirow{5}{*}{0.006} \\
\hline Overweight $(25-29.9)$ & $13(26.0 \%)$ & $12(24.0 \%)$ & $25(25.0 \%)$ & \\
\hline Obese Class I $(30-34.9)$ & $14(28.0 \%)$ & $15(13.0 \%)$ & $29(29.0 \%)$ & \\
\hline Obese Class II $(35-39.9)$ & $3(6.0 \%)$ & $13(26.0 \%)$ & $16(16.0 \%)$ & \\
\hline Obese Class III (>39.9) & $7(14.0 \%)$ & $8(16.0 \%)$ & $15(15.0 \%)$ & \\
\hline
\end{tabular}

There was no statistically significant difference in uric acid level between cases and controls, Student's t-test $=0.13$ $(P=0.900)$. Table-3 summarize the findings.

Table 3:-Uric acid level of the study groups

\begin{tabular}{|c|c|c|c|}
\hline \multirow{2}{*}{ Study Group } & \multicolumn{2}{|c|}{ Uric Acid Level } & \multirow{2}{*}{ P-value } \\
\hline & Range & Mean \pm SD & \\
\hline Case $(\mathrm{n}=50)$ & $1.40-7.20$ & $3.87 \pm 1.35$ & \multirow{3}{*}{0.900} \\
\hline Control $(\mathrm{n}=50)$ & $1.20-6.10$ & $3.90 \pm 1.02$ & \\
\hline Total $(n=100)$ & $1.20-7.20$ & $3.88 \pm 1.19$ & \\
\hline
\end{tabular}

Kellgren/Lawrence grades distribution among cases was described in details in (Table 5). Grade II showed the highest rate $20(40 \%)$ of cases while grade IV was the lowest rate of occurrence $3(6 \%)$. Uric acid was the highest $7.03 \pm 0.21$ in grade IV. Analysis of Variance (ANOVA) was utilized to calculate the statistical significance of the difference in uric acid level among the four grades; there was a strongly significant difference in uric acid level, with P-value $<0.001$. 
Table 4:-Uric acid level in each Kellgren/Lawrence grade

\begin{tabular}{|l|c|c|c|}
\hline $\begin{array}{l}\text { Kellgren/Lawrence } \\
\text { Grade }\end{array}$ & $\begin{array}{c}\text { Frequency } \\
(\%)\end{array}$ & $\begin{array}{c}\text { Uric Acid Level } \\
\text { (Mean } \pm \text { SD) }\end{array}$ & P-value \\
\hline Grade I & $15(30 \%)$ & $2.55 \pm 0.45$ & $<0.001$ \\
\hline Grade II & $20(40 \%)$ & $3.78 \pm 0.70$ \\
\hline Grade III & $12(24 \%)$ & $4.87 \pm 0.87$ \\
\hline Grade IV & $3(6 \%)$ & $7.03 \pm 0.21$ \\
\hline
\end{tabular}

Spearman's Rank-order correlation coefficient was calculated to further assess the correlation between Kellgren/Lawrence grade and the level of uric acid. There was a statistically significant positive correlation of high strength between the two variables, with correlation coefficient $(\mathrm{R})=0.844, P$-value $<0.001$. A scatter plot diagram in Figure-1 illustrates the finding.

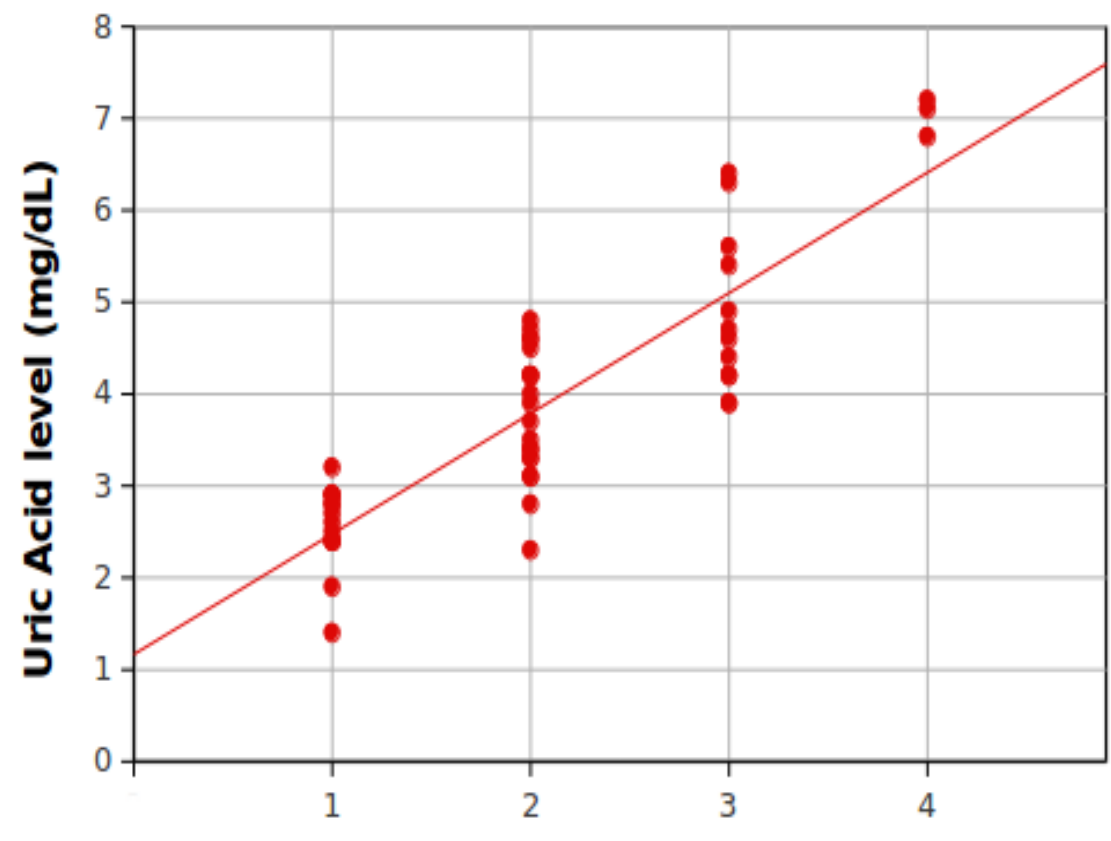

Kellgren/Lawrence grade

Fig 1:-Correlation between uric acid level (mg/dL) and Kellgren/Lawrence grade.

\section{Discussion:-}

We found there was no significant relationship between serum uric acid and nodal osteoarthritis $(\mathrm{P}-\mathrm{value}=0.900)$, this finding was in agreement with the previous studies ${ }^{(14,15,16)}$, however, there are controversial epidemiological data from both cross-sectional and cohort studies regarding the relationship between uric acid and OA ${ }^{(17,18)}$.

Although prior experiments have shown that MSU crystals, or uric acid, have a catabolic effect on cartilage and synovial inflammation, still there is controversial epidemiologic evidence regarding the association between uric acid and OA. Some earlier investigators showed interest in a causal link between uric acid and the nodal changes in hand $\mathrm{OA}^{(19,20)}$. They proposed that uric acid-induced inflammation contributed to an inflammatory response that led to nodal OA, rather than directly causing OA to develop.

Increased levels of SUA also increases morbidity and mortality in these patients (Suliman et al., 2006). It is recommended that SUA should be routinely measured in all obese and overweight patients in order to prevent or at least delay complications due to raised SUA ${ }^{(21)}$. 
In our study there is significant correlation between serum uric acid and increased age $(\mathrm{P}$-value $=0.012)$ which also has been found in other studies ${ }^{(11,22)}$. The serum level of uric acid is affected by aging and genetic and environmental factors. Obesity and alcohol consumption are well established as determinants of SUA levels ${ }^{(22,23)}$. In this study there was positive relationship between serum uric acid and radiological osteoarthritic changes of hand which has been assessed by using Kellgren-Lawrence scale (P-value $<0.001$ ), this finding was in agreement with the previous studies ${ }^{(17,18,24)}$ which mean serum uric acid level tend to raise with patients having osteoarthritic $\mathrm{K} / \mathrm{L}$ stage $\geq$ II, in this way it gives us an idea about the radiological progression. This also goes with the previous study published by Srivastava, et al. which found that the level of serum UA was found to be in increasing order, parallel to the grades of the disease. A probable mechanism of such UA related OA may be that the higher level of UA might lead to the formation of microcrystals in the joint space which is responsible for the commencement of inflammatory chain reaction leading to OA. Thus, it may be concluded that higher plasma UA levels have strong association with generalized $\mathrm{OA} / \mathrm{KOA}^{(25)}$.

\section{Limitations of this study:}

1. Small sample size due to short time.

2. The study focused only on the association of serum uric acid and nodal osteoarthritis and not on the risk of OA development.

3. We had limited information about OA involvement in each patient, including the affected joint, its severity, treatment modalities and family history of hand OA.

\section{References:-}

1. Murphy L, Schwartz TA, Helmick CG, Renner JB, et al. (2008). Lifetime risk of symptomatic knee osteoarthritis. Arthritis Care \& Research. 15;59(9):1207-13.

2. Obeid AW, Daoud MS, Alosami MH. (2012). Evaluation of Highly Sensitive C-Reactive Protein in Female Patients with Nodal Osteoarthritis. Iraqi Academic Scientific Journal. 11(4):479-84.

3. Zhang Y, Niu J, Kelly-Hayes M, Chaisson CE, et al. (2002). Prevalence of symptomatic hand osteoarthritis and its impact on functional status among the elderly: The Framingham Study. American journal of epidemiology. $1 ; 156(11): 1021-7$.

4. Barbour KE., (2016). Prevalence of severe joint pain among adults with doctor-diagnosed arthritis-United States, 2002-2014. MMWR. Morbidity and mortality weekly report; 65.

5. Patrick M, Aldridge S, Hamilton E, (1989). A controlled study of hand function in nodal and erosive osteoarthritis; Annals of the Rheumatic Diseases 48:978-982.

6. Altman R, Alarcon G, Appelrouth D, et al. (1990). The American College of Rheumatology criteria for the classification and reporting of osteoarthritis of the hand. Arthritis \& Rheumatism: Official Journal of the American College of Rheumatology. 33(11):1601-10.

7. Di Cesare PE, Haudenschild DR, Samuels J, Abramson SB. (2017). Pathogenesis of Osteoarthritis In: Firestein GR, Budd RC, Gabriel SE, McInnis IB, O’Dell JR. Kelley \& Firesteun's Textbook of Rheumatology. $10^{\text {th }}$ ed., Philadelphia: ELSEIVER, pp: 1701.

8. Mohammad NH. (2017). Salivary and Serum Levels of Both Uric Acid and C-Reactive Protein (CRP) Biomarkers in Patients with Behçet's Disease. Tikrit Journal for Dental Sciences. 5(1):143-49.

9. Chen JH, Yeh WT, Chuang SY, et al. (2012). Gender-specific risk factors for incident gout: a prospective cohort study. Clinical rheumatology. 31(2):239-45.

10. Zhu Y, Pandya BJ, Choi HK. (2011). Prevalence of gout and hyperuricemia in the US general population: The National Health and Nutrition Examination Survey 2007-2008. Arthritis \& Rheumatism. 1;63(10):3136-41.

11. Bardin T, Richette P. (2014). Definition of hyperuricemia and gouty conditions. Current opinion in rheumatology. 1;26(2):186-91.

12. Roddy E, Doherty M. (2012). Gout and osteoarthritis: a pathogenetic link. Joint Bone Spine. 5(79):425-7.

13. Kellgren JH, Lawrence JS. (1957). Radiological assessment of osteoarthritis. Ann Rheum Di.16:494-502.

14. Schouten JS, Van den Ouweland FA, Valkenburg HA. (1992). A 12 year follow up study in the general population on prognostic factors of cartilage loss in osteoarthritis of the knee. Annals of the rheumatic diseases. 1;51(8):932-37.

15. Bagge E, Bjelle A, Eden S, Svanborg A. (1991). Factors associated with radiographic osteoarthritis: results from the population study 70-year-old people in Göteborg. The Journal of rheumatology. 18(8):1218-22.

16. Kim SK, Kwak SG, Choe JY. (2016). Serum uric acid level is not associated with osteoarthritis in Korean population: data from the Seventh Korea National Health and Nutrition Examination Survey 2016. Rheumatology international. 1;38(11):2077-85. 
17. Sun Y, Brenner H, Sauerland S, Günther KP, Puhl W, Stürmer T. (2000). Serum Uric acid and patterns of radiographic osteoarthritis-the Ulm osteoarthritis study. Scandinavian journal of rheumatology. 1;29(6):380-86.

18. Acheson RM, and Collart AB. (1975). New Haven survey of joint diseases. XVII. Relationship between some systemic characteristics and osteoarthrosis in a general population. Annals of the Rheumatic Diseases. 1;34(5):379-87.

19. Srivastava RN, Sanghi D, Mishra A, Sharma A, (2014) Serum uric acid as a predisposing factor of clinicoradiological severity of osteoarthritis knee. Osteoarthr Cartil. Suppl. 22:S393

20. R.N. Srivastava y, D. Sanghi y, A. Mishra y, A.C. Sharma y, S. Raj z, S.M. Natu

21. Simkin PA, Campbell PM, Larson EB. (1983). Gout in Heberden's nodes. Arthritis \& Rheumatism: Official Journal of the American College of Rheumatology. 26(1):94-7.

22. Suliman ME, Johnson RJ, García-López E, et al. (2006). J-shaped mortality relationship for uric acid in CKD. American Journal of Kidney Diseases. 1;48(5):761-71.

23. Kuzuya M, Ando F, Iguchi A, et al. (2002). Effect of aging on serum uric acid levels: longitudinal changes in a large Japanese population group. The Journals of Gerontology Series A: Biological Sciences and Medical Sciences. 1;57(10):M660-4.

24. Campion EW, Glynn RJ, Delabry LO. (1987). Asymptomatic hyperuricemia. Risks and consequences in the Normative Aging Study. The American journal of medicine. 1;82(3):421-26.

25. Macfarlane DG, Buckland-Wright JC, Emery P, Fogelman I, Clark B, Lynch J. (1991). Comparison of clinical, radionuclide, and radiographic features of osteoarthritis of the hands. Annals of the rheumatic diseases. 1;50(9):623-26.

26. Srivastava S, Saksena AK, Khattri S, et al. (2016). Curcuma longa extract reduces inflammatory and oxidative stress biomarkers in osteoarthritis of knee: a four-month, double-blind, randomized, placebocontrolled trial. Inflammopharmacology. 1;24(6):377-88. 